\title{
A Financial Implication Analysis of Different Layer Poultry Farms in Nammakkal District, India
}

\author{
V. Dinesh and Amod Sharma* \\ Department of Agricultural Economics, SASRD, Nagaland University, Medziphema Campus, \\ Nagaland \\ *Corresponding author
}

\begin{tabular}{|l|}
\hline Ke y w or d s \\
Poultry, Layer, \\
$\begin{array}{l}\text { Economic, Farm, } \\
\text { Analysis, District }\end{array}$ \\
\hline Article Info \\
\hline $\begin{array}{l}\text { Accepted: } \\
\text { 10 May } 2019 \\
\text { Available Online: } \\
\text { 10 June } 2019\end{array}$ \\
\hline
\end{tabular}

\section{A B S T R A C T}

A study was conducted to analyze the economics of poultry layer farms in Namakkal district of Tamil Nadu state, both primary and secondary data were used. The primary data pertained to the year 2018-19 and was elicited from 100 poultry farms and 20 market intermediaries selected and data collected using pre-tested questionnaires. Tabular, financial analysis, cost concepts, marketing efficiency, garrets ranking technique was employed. The present study revealed that total costs incurred per farm on small, medium and large layer farms was Rs. 67,34,743, Rs.1,71,85305 and Rs.3,48,37873, respectively. The net returns realized by small, medium and large layer farms was Rs.409932, Rs. $12,42,392$ and Rs.3,32,6525 respectively. On the basis of net present value, benefit-cost ratio and internal rate of return, layer farms has been found that all size group layer farms are financially viable and most profitable. While the Net Present Value of investments in small farms was Rs. 1,94,926 and medium farms was Rs. 6,85,979, while that on large farms was Rs. 25,48,436 at the discount rate of 15 per cent. The benefit cost ratio was higher in large farms at 1.033 compared to that of small (1.019) and medium farms (1.030). The current study showed that the internal rate of return for the large farm was 31.15 per cent. It was higher than the small (22.89 per cent) and medium farms (23.06 per cent), respectively.

\section{Introduction}

The poultry farming plays an important role in the rural economy of India. During the last two decades, the poultry industry in India has gained a tremendous momentum and has virtually reached a stage of self-sufficiency and specialization. Rapid growth of poultry industry has been encouraging many farmers to adopt poultry farming as the main source of their income. In spite of various developments in modern poultry farming, disease problems remain as a major constraint affecting its successful functioning (Sharma et al., 1999).

Poultry business is attractive as any other business and is a home-farm enterprise. It plays an important role in converting grain and other products into eggs and poultry meat for the non-traditional benefit of mankind. 
Agriculture and poultry are interdependent as the cereals form part of feed for poultry and poultry wastages are inputs for agriculture. Poultry production can play a significant role to raise the economic status of the rural masses, improve their level of nutrition and also generate employment opportunities. Poultry farming is relatively easier and quicker and can be adapted to a wide range of climatic conditions and can generally be conveniently carried out with other farm activities like crop production, dairying and sheep rearing. Introduction of some of the world's best poultry breeds has made a major contribution to the development of the poultry programme in India. The commercial poultry farming has increasingly been taken up during recent years in almost all over the country (IPED, 2018).

There are few segments poultry industry, comprising layers, broilers and others. In the egg production layers are kept in cages during their production cycle of 72 weeks. Once their productivity declines, they are sold in the market for consumption. Income from layer farm poultry products includes sale of eggs, cull birds, gunny bags and manure. India is marching ahead towards attaining nutritional security for its people. In this context, poultry eggs, which is highly nutritious and the cheapest source of high quality protein and the poultry meat that is comparatively less expensive than that of red meat (Vengoto and Sharma (2018).

\section{Materials and Methods}

Table 1 reveals that the Namakkal and tiruchengode taluks were purposively selected as these have relatively large number of poultry (layer) farms as compared to other taluks of the district. A list of poultry farms located in each of the selected taluks in Namakkal district was prepared with the help of the staff of the department of animal husbandry. From the list 100 layer farms are selected out of which 25 farms are selected from four blocks or village divisions, the blocks include Namakkal, ernapuram, elachipalayam, mallasamathuram, out of this four blocks Namakkal and ernapuram comes under Namakkal taluk whereas elachipalayam and mallasamuthram comes under tiruchengode taluk. The farms are selected based on multistage random and purposive sampling technique. After collection of data the selected farms are classified in to three groups as small, medium, large based on the number of poultry birds using the mean plus or minus standard deviation formula. The birds size less than 11,200 comes under small which included 10 farms, the birds size from 11,200 to 87000 comes under medium farms which included 69 farms and the bird size of above 87000 is taken as large farms which include 21 farms, all the 100 layer farms are selected in the study area are done without looking in to the population. For the purpose of analyzing the marketing aspects of eggs, 10 wholesalers and 10 retail egg centres were selected randomly.

Table 2 reveals that the tabular presentation method was followed to study the general characteristics of sample poultry farmers, determine the resource structure, returns and profits. Simple statistical tools like averages and percentages were used in to arrive at meaningful results. Similar findings were found out by Aruputharaj and Devi (1979).

The techniques used for the financial analysis were:

\section{Net Present Value (NPV)}

The present value represents the discounted value of the net cash inflows to the project. In the present study, a discount factor of 15 per cent was used to discount the net cash inflows representing the opportunity cost of capital. 
It is the discounted value of net cash flow of the poultry unit during its life time. It is computed as:

$N P V=\sum_{i=1}^{N} \frac{\left(B_{t}-C_{t}\right)}{(1+r)^{t}}-I$

Whereas:

$\mathrm{B}_{\mathrm{t}}=$ Benefits in period ' $\mathrm{t}$ '

$\mathrm{C}_{\mathrm{t}}=$ Cost in period ' $\mathrm{t}$ '

$r=$ Discount rate

$\mathrm{t}=$ Project life

$\mathrm{I}=$ Initial investment.

For feasibility of investment, NPV should be positive at prevailing market rate of interest.

\section{Benefit-Cost Ratio (BCR)}

The benefit cost ratio (BCR) was worked out by using following formula

$$
B C R=\frac{\sum_{i=1}^{n} \frac{\left(B_{t}\right)}{(1+r)^{t}}}{\sum_{i=1}^{n} \frac{\left(C_{t}\right)}{(1+r)^{t}}}
$$

If $\mathrm{BCR}$ is greater than one, the investment is considered feasible.

\section{Internal Rate of Return (IRR)}

The internal rate of return is that rate of discount at which NPV is zero. It is calculated by using following Formula:

$$
I R R=N P V=\sum_{i=1}^{N} \frac{\left(B_{t}-C_{t}\right)}{(1+r)^{t}}-I=0
$$

If IRR is greater than prevailing rate of interest, then investment is feasible.

\section{Results and Discussion}

Table 3 reveals that the tests of financial feasibility of investments on layer farms are presented in the table that the Net Present Value of investments in small farms was Rs. $1,94,926$ and medium farms was Rs. $6,85,979$, while that on large farms was Rs. $25,48,436$. Higher net present value for large farms showed higher returns. A look at the table shows that the benefit cost ratio was higher in large farms at 1.033 compared to that of small (1.019) and medium farms (1.030). This test also proved that the economies of scale can operate on different size groups of farms and the investment on large farms was more worthwhile than small and medium farms. Similar findings were find out in the line with Choudhary et al., (2017).

Further table 3 reveals that the internal rate of return which indicates the rate at which the investment can completely recovered $(\mathrm{NPV}=0)$ and which may be compared with the ruling rate of interest for investment decisions. The current study showed that the internal rate of return for the large farm was 31.15 per cent. It was higher than the small (22.89 per cent) and medium farms (23.06 per cent), thus, it is profitable in all the layer farm size groups. The present findings were also done by the other researchers in this line with Kent and Sharma (2014); Sharma et al., (2000) for supporting the present results and findings, respectively.

Table 4 reveals that the total costs and various returns involved in the production of eggs is presented in the table and returns realized, Net return was calculated. The farmers were differentiated in to three categories based on the number of layer birds present.

Accordingly birds size of up to 11,200 are taken as small size poultry farms which has average poultry birds size of 5800 likewise population of 11,200 to 87,000 are considered as medium size farms which has average birds size of 14,652 and birds population above 87000 are considered as large size farms, 
respectively. Similar findings were in the line with the findings of the Sharma et al., (2002); Kent and Sharma (2014) and Sharma et al., (2000) for supporting the results.

Table 5 reveals that the variable cost is high compared to fixed cost in layer farms. The high variable cost is due to large amount spend on feeds, feeds alone account for more than 90.00 per cent and next highest cost incurred for chicks followed by vaccination charges and cost incurred for labours. Feed cost for layer farms are less with (92.18 per cent) compared to small (92.28 per cent) and medium farms (93.16 per cent) due to the use of own feed from their farms, respectively.

Similar findings were in the line with Kent and Sharma (2014).

Table 5 further reveals that the average production of eggs for one batch of layers in small, medium, large farms was found to be 171100 numbers, 4406304 numbers, 9159762 numbers, respectively (Fig. 1).

Table.1 Taluk wise total poultry population, total number of farms

\begin{tabular}{|c|l|c|c|}
\hline S. No. & \multicolumn{1}{|c|}{ Name of the taluk } & Number of farms & Number of birds \\
\hline $\mathbf{1 .}$ & Namakkal & 499 & 24379800 \\
\hline $\mathbf{2 .}$ & Rasipuram & 130 & 6372800 \\
\hline $\mathbf{3 .}$ & Paramathivelur & 35 & 1875500 \\
\hline $\mathbf{4 .}$ & Tiruchengode & 168 & 59744500 \\
\hline $\mathbf{5 .}$ & Sendhamangalam & 30 & 2027500 \\
\hline $\mathbf{6 .}$ & Kohill hills & 0 & 0 \\
\hline $\mathbf{7 .}$ & Komarapalayam & 3 & 185000 \\
\hline & \multicolumn{1}{|c|}{ Total } & 865 & 40815050 \\
\hline
\end{tabular}

(Source: district animal husbandry office, Namakkal, 2017-2018)

Table.2 Number of sample layer farms selected

\begin{tabular}{|c|l|c|c|}
\hline S. No. & \multicolumn{1}{|c|}{ Taluks } & Village divisions & Number of farms \\
\hline $\mathbf{1 .}$ & NAMAKKAL & Ernapuram & $25(25.00)$ \\
\cline { 3 - 4 } & & Namakkal & $25(25.00)$ \\
\hline \multirow{2}{*}{ 2. } & \multirow{2}{*}{ TIRUCHENGODE } & Elachipalayam & $25(25.00)$ \\
\cline { 3 - 4 } & & mallasamutharam & $25(25.00)$ \\
\hline & & & $100(100.00)$ \\
\hline
\end{tabular}

(Source: field study)

Table.3 Financial analysis of different layer farms

\begin{tabular}{|c|l|c|c|c|}
\hline S. No. & CATEGORY & $\begin{array}{l}\text { NET PRESENT } \\
\text { VALUE } \mathbf{( R s )}\end{array}$ & BC RATIO & $\begin{array}{l}\text { INTERNAL RATE OF } \\
\text { RETURN (\%) }\end{array}$ \\
\hline $\mathbf{1 .}$ & Small farms & $1,94,800$ & 1.019 & 22.88 \\
\hline $\mathbf{2 .}$ & Medium farms & $6,85,653$ & 1.03 & 23.06 \\
\hline 3. & Large farms & $25,47,013$ & 1.033 & 31.14 \\
\hline
\end{tabular}


Table.4 Cost of production for different layer farm groups

\begin{tabular}{|c|c|c|c|c|}
\hline \multirow[t]{2}{*}{ S. No. } & \multirow[t]{2}{*}{ PARTICULARS } & \multicolumn{3}{|c|}{ FARMER CATEGORY } \\
\hline & & Small & Medium & Large \\
\hline 1. & \multicolumn{4}{|l|}{ Variable cost: } \\
\hline a. & Chick cost & $\begin{array}{c}208800 \\
(3.00)\end{array}$ & $\begin{array}{c}527478 \\
(3.11)\end{array}$ & $\begin{array}{c}1063714 \\
(3.12)\end{array}$ \\
\hline b. & Vaccination charges & $\begin{array}{l}96000 \\
(1.44)\end{array}$ & $\begin{array}{c}240765 \\
(1.42)\end{array}$ & $\begin{array}{c}480762 \\
(1.41)\end{array}$ \\
\hline c. & Debeaking cost & $\begin{array}{c}1800 \\
(0.027)\end{array}$ & $\begin{array}{l}5197 \\
(0.03)\end{array}$ & $\begin{array}{l}12019 \\
(0.03)\end{array}$ \\
\hline d. & \multicolumn{4}{|c|}{ Feed cost } \\
\hline i). & Starter feed & $\begin{array}{c}280627 \\
(4.20)\end{array}$ & $\begin{array}{c}707976 \\
(4.18)\end{array}$ & $\begin{array}{c}1403157 \\
(4.11)\end{array}$ \\
\hline ii). & Chick mash & $\begin{array}{l}55680 \\
(0.83)\end{array}$ & $\begin{array}{c}140661 \\
(0.83)\end{array}$ & $\begin{array}{c}283657 \\
(0.83)\end{array}$ \\
\hline iii). & Grower feed & $\begin{array}{c}475315 \\
(7.16)\end{array}$ & $\begin{array}{c}1218386 \\
(7.20)\end{array}$ & $\begin{array}{c}2417404 \\
(7.09)\end{array}$ \\
\hline iv). & Layer feed & $\begin{array}{c}5310576 \\
(80.09)\end{array}$ & $\begin{array}{c}13693416 \\
(80.95)\end{array}$ & $\begin{array}{c}27303023 \\
(80.15)\end{array}$ \\
\hline e. & Labour charges & $\begin{array}{c}180000 \\
(2.71)\end{array}$ & $\begin{array}{c}229052 \\
(1.35)\end{array}$ & $\begin{array}{c}802429 \\
(2.35)\end{array}$ \\
\hline f. & Insurance fee & $\begin{array}{c}0 \\
(0.00)\end{array}$ & $\begin{array}{c}104438 \\
(0.61)\end{array}$ & $\begin{array}{c}132964 \\
(0.39)\end{array}$ \\
\hline g. & Electricity & $\begin{array}{l}9180 \\
(0.13)\end{array}$ & $\begin{array}{l}17757 \\
(0.10)\end{array}$ & $\begin{array}{c}101486 \\
(0.29)\end{array}$ \\
\hline \multirow[t]{2}{*}{ h. } & Miscellaneous cost & $\begin{array}{l}12000 \\
(0.18)\end{array}$ & $\begin{array}{l}30096 \\
(0.17)\end{array}$ & $\begin{array}{l}60095 \\
(0.17)\end{array}$ \\
\hline & & 6629978 & 16915222 & 34060710 \\
\hline 2. & \multicolumn{4}{|l|}{ Fixed cost: } \\
\hline a. & Depreciation & $\begin{array}{c}67362 \\
(64.50)\end{array}$ & $\begin{array}{l}158428 \\
(58.84)\end{array}$ & $\begin{array}{l}409372 \\
(52.93)\end{array}$ \\
\hline b. & Land value & $\begin{array}{c}30667 \\
(29.36)\end{array}$ & $\begin{array}{l}94300 \\
(35.02)\end{array}$ & $\begin{array}{l}292063 \\
(37.76)\end{array}$ \\
\hline c. & Interest on fixed capital & $\begin{array}{l}6736 \\
(6.12)\end{array}$ & $\begin{array}{l}17355 \\
(6.12)\end{array}$ & $\begin{array}{l}75727 \\
(9.30)\end{array}$ \\
\hline & & 104765 & 270083 & 777162 \\
\hline \multicolumn{2}{|c|}{ 3. Total cost $(\mathrm{TVC}+\mathrm{TFC})$} & 6734743 & 17185305 & 34837873 \\
\hline
\end{tabular}

(The figures in the parenthesis indicate the percentage to the total) 
Table.5 profit measure for different layer farm groups

\begin{tabular}{|c|l|c|c|c|}
\hline \multirow{2}{*}{ S. No. } & \multicolumn{2}{|c|}{ PARTICULARS } & \multicolumn{3}{c|}{ FARM GROUPS } \\
\cline { 3 - 5 } & & SMALL & MEDIUM & LARGE \\
\hline $\mathbf{1 .}$ & FIXED COST & 104765 & 270083 & 777162 \\
\hline $\mathbf{2 .}$ & VARIABLE OST & 6629979 & 16915222 & 34060711 \\
\hline $\mathbf{3 .}$ & TOTAL COST & 6734744 & 17185305 & 34837873 \\
\hline $\mathbf{4 .}$ & COST A & 7147189 & 18469255 & 37674993 \\
\hline $\mathbf{5 .}$ & COSTA $_{2}$ & 7147189 & 18469255 & 37674993 \\
\hline $\mathbf{6 .}$ & COST B & 7153925 & 18486611 & 37750720 \\
\hline $\mathbf{7 .}$ & COST C & 7333925 & 18603480 & 37781577 \\
\hline $\mathbf{8 .}$ & NO OF EGGS & 1711000 & 4406304 & 9159762 \\
\hline $\mathbf{9 .}$ & TOTAL PRICE OF EGGS & 6501800 & 16743957 & 34807095 \\
\hline $\mathbf{1 0 .}$ & INCOME FROM GUNNY BAG \& & 642876 & 1683741 & 3357303 \\
\hline $\mathbf{1 1 .}$ & MANURE \& CULLED BIRDS & & & \\
\hline $\mathbf{1 2 .}$ & GROSS RETURN & 7144676 & 18427698 & 38164398 \\
\hline $\mathbf{1 3 .}$ & BENEFIT COST RATIO & 409932 & 1242392 & 3326525 \\
\hline
\end{tabular}

Fig.1 Financial analysis of different layer farm groups

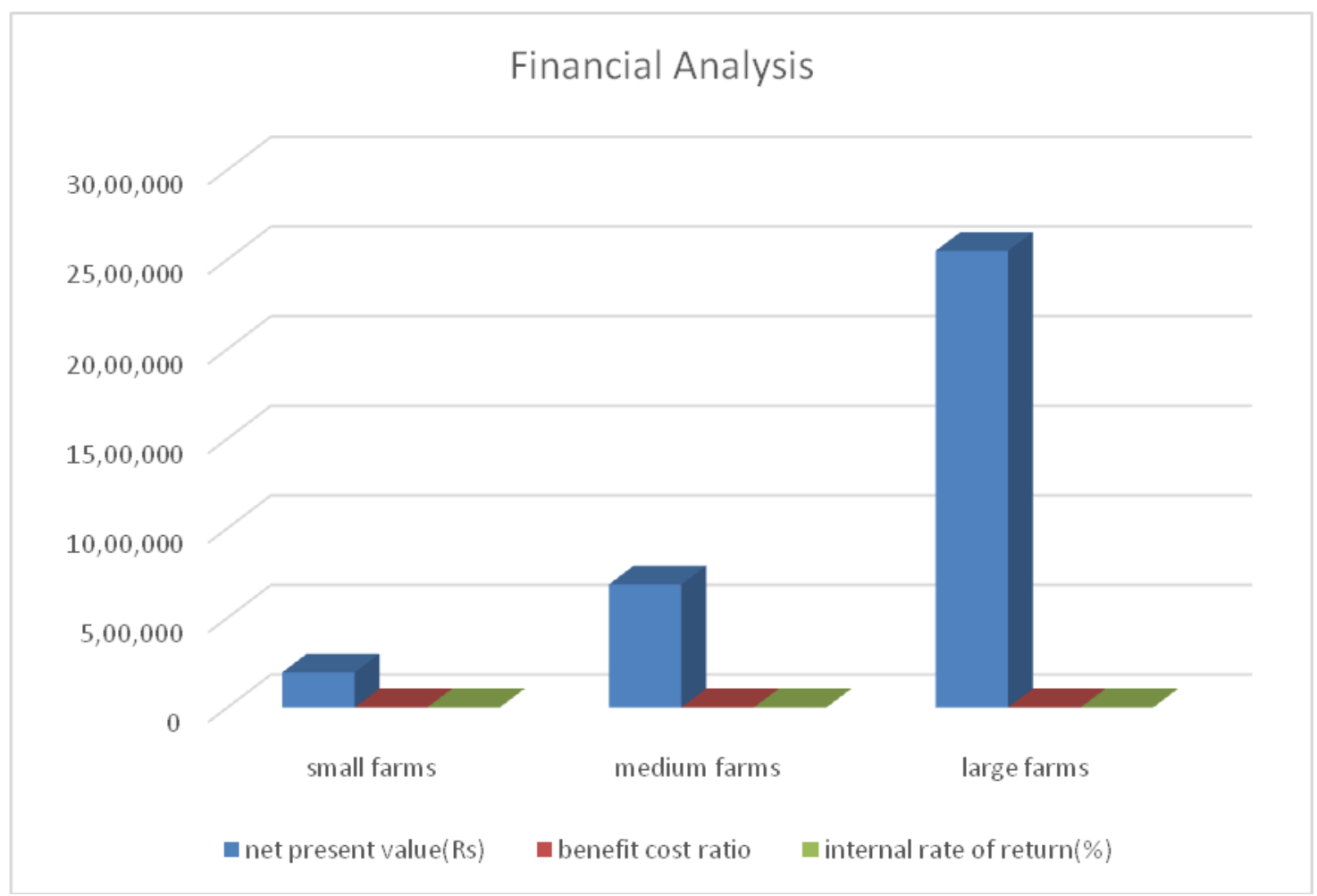


Fig.2 Profit measure for different layer farm groups

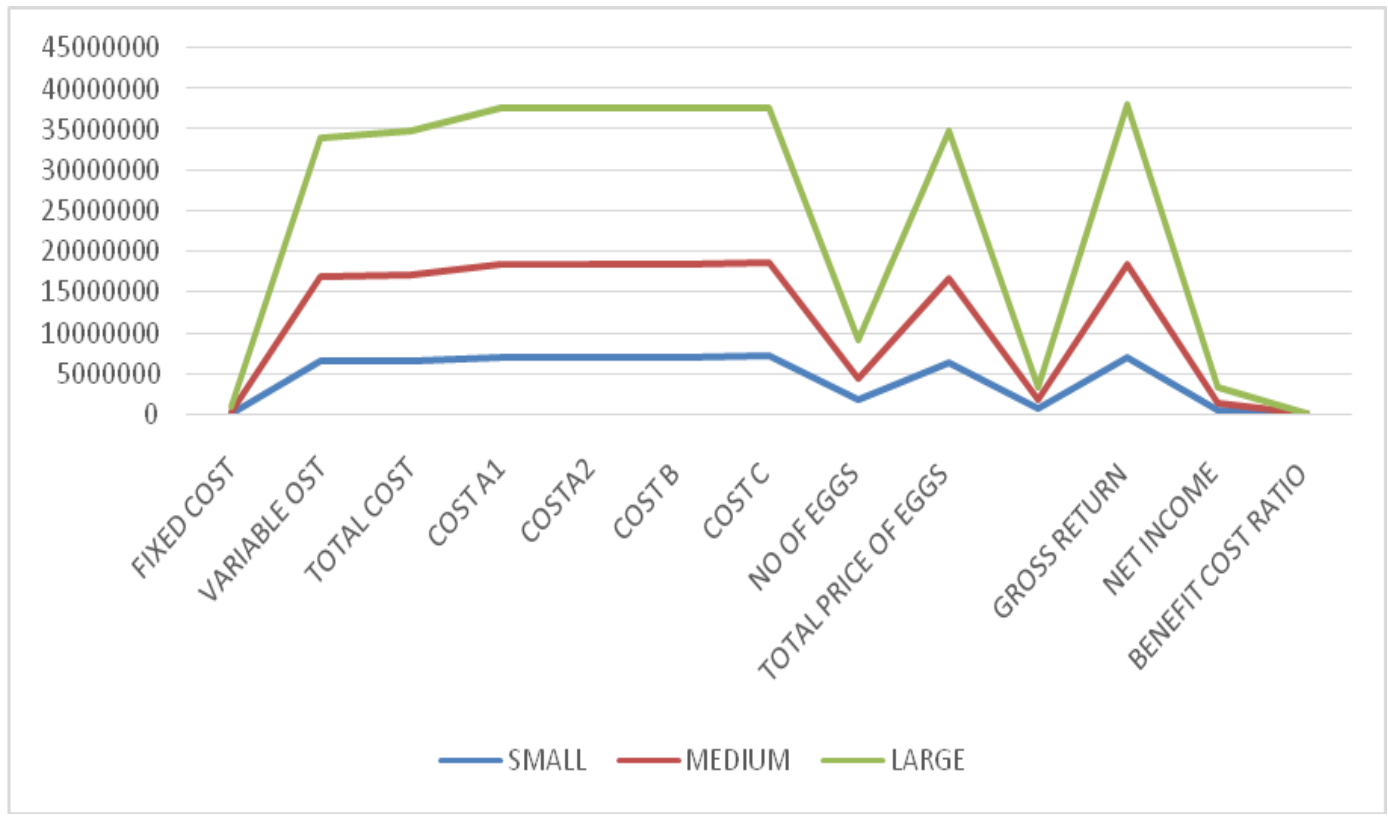

Taking the average price per egg at Rs.3.8, the income from egg was observed to be Rs.6501800, Rs.16743957, Rs.34807095, respectively. Income from sale of gunny bags, manure and culled birds was found to be Rs.642876, Rs.16837411, Rs.3357303for all the three size of farms. In total gross income for all the three farms was found to be Rs.7144676, Rs.18427698, Rs.38164398, respectively. The net income was found to be Rs.409932 for small farms. The net income for medium farms was Rs. 1242392 and net income for large farms was Rs. 3326525. Large farms have higher net income due to reduction in feed cost from their use of own feed. The total Benefit Cost Ratio was around 1.061, 1.072 and 1.095 for small, medium and large farms. The Benefit cost was highest in large farms compared to small and medium farms, respectively. Similar findings were in the line with Sharma (2015) (Fig. 2).

Table 5 reveals that the working expenses incurred during production of eggs and also includes depreciation on buildings and equipment, land revenue and other miscellaneous expenses for one batch of layer farms. On an average, the Cost $A_{1}$ was found to be Rs. 7147189 , Rs. 18469255 and Rs. 37674993 for small, medium and large farms, respectively. Cost $A_{2}$ included the Cost $A_{1}$ and the rent paid for leased in land. Cost $\mathrm{A}_{2}$ remained equivalent to Cost $A_{1}$ as the land was owned by the farmers and hence there was no leased in or leased out of land involved.

The Cost $\mathrm{A}_{2}$ for small, medium, large farms was found to be Rs. 7147189 , Rs. 18469255 and Rs. 37674993, respectively. The Cost B was calculated by summing up the interest on the capital assets (excluding land) with the amount of Cost $A_{1}$. The Cost $B_{1}$ for small, medium and large farms was Rs. 7153925 , Rs. 18486611 and Rs. 37750720, respectively. Cost $\mathrm{C}$ was calculated by adding the imputed value of family labour to Cost $\mathrm{B}$. Cost $\mathrm{C}$ for small, medium and large farms was Rs.7333925, Rs.18603480 and Rs.37781577, respectively. Similar findings were in the line with Sharma (2018), respectively. 
In conclusion, the Net Present Value of investments in small farms was Rs. 1,94,926 and medium farms was Rs. $6,85,979$, while that on large farms was Rs. $25,48,436$ at the discount rate of 15 per cent. The benefit cost ratio was higher in large farms at 1.033 compared to that of small (1.019) and medium farms (1.030).

The current study showed that the internal rate of return for the large farm was 31.15 per cent per cent. It was higher than the small (22.89 per cent) and medium farms (23.06 per cent), respectively. The gross returns were Rs. 7144676 per farm on small layer farms, Rs. 18427698 on medium farms, Rs. 38164398 on large farms. The net return obtained on small layer farms was Rs.409932, medium farms was Rs.1242392 and in large farms was Rs.3326525. The total Benefit Cost Ratio was around 1.061, 1.072 and 1.095 for small, medium and large farms, respectively.

\section{Policy Implications}

Based on the findings of the present investigation following policy implications are drawn:

1. From the analysis it's found that, layer farms are found financially feasible. Thus, farmers may be encouraged to take up layer farming as their major activity.

2. It was observed from the study that as the farm size increases the cost per bird decreases and the profit per bird also increases hence, the poultry farmers may advised to take up layer enterprise on large scale.

3. The feeds contribute about 80.00 per cent to the total production costs. Large layer farms having feed mill get high reduction of variable cost. Government Poultry organizations can produce feeds and supply it to the small and medium farms.

\section{References}

Analogous. 2011. Agriculture and Industry Survey. Business Magazine for Agriculture, Indian Poultry Industry. October 20.

Aruputharaj, C. and Devi, Kamala, P. 1979. Economics of Poultry Farming in Tamil Nadu. Madras Agricultural Economics Research Centre, University of Madras. P. 79.

Choudhary, Ramjilal.; Rathore, D.S. and Sharma, Amod. 2017. An Economics Analysis of Production and Marketing of Groundnut in Porbandar District of Gujarat. Economic Affairs. 62(3) September: 547-553.

Kent, Yuntilo. and Sharma, Amod. 2014. Economic Efficiency on different breeds of Poultry birds under Backyard Management System in Dimapur district of Nagaland. Progressive Agriculture. 14(1): 168-177.

Paney, Yani. and Sharma Amod. 2018. Prioritization Strategies for the Resources of Traditional Paddy-CumFish Culture in Lower Subansiri District of Arunachal Pradesh. International Journal of Current Microbiology and Applied Sciences. 7(5). May: 11121124.

Sharma, A. Chauhan, S. Singh, A. K. Sharma, S. K. and Singh, S. P. 2000. Economics Of Milk Production on Different Farm Size Groups. Dairy Guide. XXI(3-4). July to December: 61-66.

Sharma, A. Jha, K. K. and Kulshresthra, R. K. 1999. Human labour availability and utilization pattern in co-operative dairy sector in Agra District of U.P. Dairy Guide. XX(1-2) January to June: 17-21. Sharma, A. Sharma, Anamika. and Sharma, S. K. 2002. The scope of improving the existing system of Poultry farming. Bioved. 13(1-2). February to August: 147-150. 
Sharma, Amod. 2015. Growth and Variability in area, Production and Yield of Cotton Crop. International Journal of Agriculture Innovations \& Research. 4(3). November: 509-511.

Vengoto, Venyo and Sharma, Amod. 2018.
Economic and Constraint of Potato crop in Kohima district of Nagaland. Technoframe. 7(1):75-80. www.tanuvas.ac.in/nea/docs/IPED/pdf. Assessed on 08th May 2018.

\section{How to cite this article:}

Dinesh, V. and Amod Sharma. 2019. A Financial Implication Analysis of Different Layer Poultry Farms in Nammakkal District, India. Int.J.Curr.Microbiol.App.Sci. 8(06): 938-946. doi: https://doi.org/10.20546/ijcmas.2019.806.113 